\title{
HANDWRITTEN MISCELLANIES ABOUT PETER THE GREAT: CODICOLOGICAL PROBLEMS ${ }^{1}$
}

\author{
Tatyana A. Bazarova \\ Saint Petersburg Institute of History of RAS, Saint Petersburg, Russian Federation \\ Irina A. Voznesenskaya \\ Library of RAS, Saint Petersburg, Russian Federation
}

\begin{abstract}
The readings on the history of Peter's time seem to be quite stable. These included works written in Petrine time, some of which were published in the first quarter of the 18th century, the chronological tables of Peter the Great's reign, often with a poetic preface, as well as biographical works by P.N. Krekshin and A. Katiforo, created in Elizabethan time and distributed as copies.

The first biographical works about the tsar-reformer were often supplemented by handwritten copies of printed decrees, communiques, letters and other documents. In addition, handwritten miscellanies, consisting exclusively of letters and decrees of Peter the Great, were distributed.

In the late 18th - early 19th century handwritten miscellanies about Peter the Great became a subject of interest among collectors and academics. Therefore, at present, these manuscripts can be found in various collections in archives and libraries. The collection's being part of the family fund gives the researcher an opportunity to talk more confidently about owner and the purposes of compilation. The collections lack necessary historical convoy, and it is very difficult to trace the origin of the manuscript.

Codicological research provides an opportunity to clarify the origin, the sociocultural milieu and the further archival being of the miscellanies about Peter the Great.

Key words: handwritten miscellanies, Peter the Great, Petrine era, $18^{\text {th }}$ century, codicology, owner's inscriptions.

Citation. Bazarova T.A., Voznesenskaya I.A. Handwritten Miscellanies About Peter the Great: Codicological Problems. Vestnik Volgogradskogo gosudarstvennogo universiteta. Serija 4, Istorija. Regionovedenie. - Mezhdunarodnye otnoshenija [Science Journal of Volgograd State University. History. Area Studies. 호 International Relations], 2017, vol. 22, no. 3, pp. 75-84. (in Russian). DOI: https://doi.org/10.15688/jvolsu4.2017.3.7.

\section{РУКОПИСНЫЕ СБОРНИКИ О ПЕТРЕ ВЕЛИКОМ:} ПРОБЛЕМА КОДИКОЛОГИЧЕСКОГО ИЗУЧЕНИЯ ${ }^{1}$

Татьяна Анатольевна Базарова

Санкт-Петербургский институт истории РАН, г. Санкт-Петербург, Российская Федерация

Ирина Александровна Вознесенская

Библиотека РАН, г. Санкт-Петербург, Российская Федерация 
Аннотация. Круг чтения, связанный с историей Петровской эпохи, представляется стабильным. Это сочинения, созданные в петровское время, некоторые из которых были опубликованы до 1725 г., хронологические таблицы царствования Петра Великого, часто со стихотворным предисловием, а также биографии первого российского императора, сочиненные П.Н. Крекшиным и А. Катифоро в елизаветинское время и получившие широкое распространение в списках. Первые биографические труды о царе-реформаторе часто дополнялись рукописными копиями печатных указов, реляций, писем и других документов. Распространение также получили сборники, состоящие исключительно из писем и указов Петра Великого.

В конце XVIII - начале XIX в. сборники о Петре Великом стали предметом интереса собирателей и ученых. Поэтому в настоящее время эти рукописи можно обнаружить в различных фондах и коллекциях архивов и библиотек. Принадлежность сборника семейному фонду дает возможность более уверенно рассуждать о его заказчике и целях составления. В коллекциях отсутствует необходимый исторический конвой, и проследить происхождение рукописи весьма затруднительно.

Кодикологическое исследование дает возможность уточнить обстоятельства создания, среду бытования и дальнейшую архивную судьбу сохранившихся до наших дней рукописных сборников о Петре Великом.

Ключевые слова: рукописные сборники, Петр Великий, петровское время, XVIII в., кодикология, владельческие надписи.

Цитирование. Базарова Т. А., Вознесенская И. А. Рукописные сборники о Петре Великом: проблема кодикологического изучения // Вестник Волгоградского государственного университета. Серия 4, История. Регионоведение. Международные отношения. - 2017. - Т. 22, № 3. - C. 75-84. - DOI: https://doi.org/10.15688/jvolsu4.2017.3.7.

Традиция создания рукописных книг в России продолжалась в течение веков, несмотря на развитие книгопечатания и широкое распространение печатной книги. Рядом с типографскими изданиями на полках семейных библиотек по-прежнему стояли и рукописные книги. Историк и книговед С.П. Луппов обратил внимание на то, что сохранению практики «списывания» как печатных, так и рукописных материалов способствовали, прежде всего, ограниченность репертуара и дороговизна изданий. Владелец библиотеки мог существенно сократить свои расходы, скопировав заинтересовавшую его книгу [13, с. 186$187,190]$. Таким образом создавались многочисленные списки отдельных произведений или тематические сборники, куда включались различные исторические и литературные сочинения, а также мемуары и документы.

Исследование сборников XVIII - начала XIX в. имеет не столь обширную историографию, как рукописная традиция допетровского периода. В первую очередь они привлекали внимание историков литературы и книговедов $[15 ; 16 ; 21 ; 24 ; 25]$. До сих пор единственным монографическим исследованием рукописных сборников XVIII в. остается написанная в 1930-е гг. и опубликованная в 1963 г. книга М.Н. Сперанского (1863-1938) [38]. В ней ученый проанализировал состав более пятисот сборников, разделив их на пять основных групп, являвшихся «характерными и показательными для литературного чтения в демократических классах России XVIII в.» [38, с. 29]. Проблемы бытования рукописных сборников XVIII в. в различной социальной среде также рассматривал книговед и палеограф Н.Н. Розов (1912-1993) [23]. В современной историографии предложенная М.Н. Сперанским социокультурная типология сборников [38, с. 99] подвергается сомнению. Так, О.Н. Фокина отметила искусственность четкого разграничения читательских интересов по сословиям [39, с. 250].

В XVIII в. в русскую рукописную традицию вошла «петровская тема», что было связано с попытками младших современников первого российского императора и их потомков осмыслить личность и деятельность Петра Великого. Появившиеся в елизаветинское и екатерининское время сочинения о петровском царствовании нередко распространялись в списках задолго до выхода публикации из типографии. Наиболее ярким примером стала судьба произведений одного из первых биографов Петра I- П.Н. Крекшина (1684-1763). Младший современник первого российского императора новгородский дворянин П.Н. Крекшин на протяжении нескольких десятилетий собирал и копировал документы петровского времени, чтобы на их основе написать историю Петра Великого. В 1742 г. он поднес императрице Елизавете Петровне «Краткое описание блаженных дел великого 
государя императора Петра Великого, самодержца всероссийского, собранное через недостойные труды последнейшего раба Петра Крекшина, дворянина Великого Новгорода», в котором довел жизнеописание царя до 1706 года. С.А. Мезин отметил, что главным делом своей жизни сам П.Н. Крекшин считал составление подробных «Журналов», в которых описывал каждый день жизни Петра I $[14$, с. 89]. Над биографией Петра Великого (которую он так и не закончил) новгородский дворянин продолжал трудиться до конца своих дней.

После смерти П.Н. Крекшина его бумаги разошлись по частным собраниям, во второй половине XIX в. часть материалов была передана Археографической комиссии. Рукописный список его сочинения о начале царствования Петра Алексеевича, хранившийся в семейной библиотеке Шереметевых, стал основой для первой публикации, подготовленной в 1787 г. В.Г. Вороблевским. Правда, труд П.Н. Крекшина, в котором повествование заканчивалось описанием стрелецкого бунта 15 мая 1682 г., опубликовали без указания автора [36]. В том же 1787 г. другой рукописный список «Сказания», заканчивавшийся 1683 г., Ф.О. Туманский включил в свое «Собрание записок о Петре Великом» [37]. Отметим, что в том же сборнике были опубликованы и «Записки о стрелецком бунте» А.А. Матвеева. В дальнейшем уже эти публикации копировались и в рукописном виде входили в состав сборников о Петре Великом конца XVIII начала XIX века.

По мнению М.Н. Сперанского, в светских сборниках XVIII в. история царствования Петра Великого являлась одной из главных. Ученый отмечал широкое бытование, как отдельных статей, так и целых сборников, посвященных Петру и его времени [38, с. 3339]. Основой для исследования М.Н. Сперанского стали, прежде всего, рукописные материалы ГБЛ и ГИМ, ГПБ им. М.Е. Салтыкова-Щедрина, а также ряда других архивных и библиотечных собраний [38, с. 174-180].

Выводы исследователя подтверждает анализ содержания сборников XVIII-XIX вв., хранящихся в БАН [18] (М.Н. Сперанским были выявлены только некоторые из них) [38, с. 174]. Из 341 сборника, включенного в тре- тий выпуск «Описания Рукописного отдела БАН СССР», около 100 рукописей - это различные сочинения о царствовании Петра I и копии документов петровского времени. Судя по их составу, особой популярностью у читателя XVIII в. пользовались сочинения П.Н. Крекшина о рождении и первых годах царствования Петра Великого, записки А.А. Матвеева о стрелецком бунте и слова Феофана Прокоповича. Из переводной литературы наиболее часто встречаются списки выполненного по поручению Елизаветы Петровны Стефаном Писаревым перевода «Жития Петра Великого» аббата Антонио Катифоро (оригинал был опубликован на итальянском в 1736 г.; русский перевод вышел из печати только при Екатерине II) [2].

В тех случаях, когда оригиналы документов утрачены, выявление и сравнение различных списков приобретает особо важное источниковедческое значение. Подобную кропотливую работу проделали с рядом рукописных копий издатели «Путешествия по Европе боярина Б.П. Шереметева: 1697-1699» [17]. Они установили наличиепространной, сокращенной, краткой и особой редакций данного сочинения. В результате исследования хранящихся в БАН пространных редакций «Путешествия» был сделан вывод о том, что эти списки выполнены с печатного издания [17, с. 340-341].

Нередко первые сочинения о царе-реформаторе дополнялись рукописными копиями печатных указов, реляций и других документов. Отметим также существование разнообразных сборников, состоящих исключительно из писем и указов Петра Великого (как печатных, так и рукописных). Так, в собраниях архивов и библиотек до наших дней сохранились многочисленные копии сборников писем Петра Ф.М. Апраксину. Е.П. Подъяпольская, анализируя сохранность эпистолярного наследия Петровской эпохи, обратила внимание на то, что подлинники этих писем были утрачены уже в XIX в. [20]. Составители «Писем и бумаг Петра Великого» помещали в свой многотомный труд копии писем государя, адресованные адмиралу, из рукописных сборников XVIII века.

В настоящее время в Архиве СПбИИ РАН в различных фондах и коллекциях выявлено четыре списка сборников писем Петра I Ф.М. Апраксину [5-8]. Два сборника, судя по 
старым шифрам на переплетах, ранее (до начала 1930-х гг.) хранились в БАН [5-6]. На переплетном листе одной из рукописей сохранилась владельческая надпись: «Петр Демидов. № 8» [6]. Это позволяет предположить, что книга происходила из фамильной библиотеки знаменитых горнозаводчиков. Однако последовательное кодикологическое изучение рукописных сборников писем Петра Великого Ф.М. Апраксину пока непредпринималось.

Уже в конце XVIII - начале XIX в. сборники о Петре Великом стали предметом собирательского интереса коллекционеров и ученых, поэтому в настоящее время эти рукописи можно обнаружить в различных фондах и коллекциях архивов и библиотек. Принадлежность семейному фонду дает возможность более уверенно рассуждать о заказчике и целях составления того или иного сборника. Например, в фонде Воронцовых (ф. 36) Архива СПбИИ РАН сохранились рукописные копии исторических, географических и литературных сочинений и документов Петровской эпохи. Историей интересовались многие представители семьи Воронцовых, но больше всего исторических сборников связано с именами Михаила Илларионовича и Александра Романовича ${ }^{2}$. Для М.И. Воронцова делались выписки из архивных бумаг Петра Великого и его сподвижников [19, с. 107]. По-видимому, в середине - второй половине XVIII в. семейную библиотеку Воронцовых пополнили несколько томов копии реляций А.Д. Меншикову [9-12], перевод «Жития Петра Великого» Антонио Катифоро [3, 4], «Хронологические записки достопамятных в России происшествий» с рождения Петра Алексеевича и до 1765 г. [40] и др.

Значительная часть сборников отложилась в коллекциях как исторически сложившихся в результате собирательской деятельности коллекционеров, так и сформированных уже в архивах и библиотеках. Заложенная еще Императорской Археографической комиссией традиция формирования коллекций по видовому признаку документов (напр., создавались коллекции актов, карт и планов, рукописных книг) продолжалась и в советское время. В искусственно созданных коллекциях отсутствует необходимый исторический конвой и зачастую проследить происхожде- ние рукописи весьма затруднительно. Только тщательное кодикологическое исследование дает ученому возможность выявить владельцев и заказчиков, а следовательно, определить среду и особенности бытования тех или иных сборников.

Так, в Коллекции текущих поступлений БАН отложился рукописный сборник, состоящий из «Службы перенесению мощей» и «Жития Александра Невского» с перечнем городов, взятых русскими войсками в ходе Северной войны, похвальными словами Феофана Прокоповича, «Рассуждением о причинах Свейской войны» П.П. Шафирова и «Истории о зачатии и рождении Петра» П.Н. Крекшина [34]. Эта рукопись иллюстрирована рисунками пером и наклеенными гравированными изображениями, в большинстве случаев раскрашенными. В конце помещена «портретная галерея» от Рюрика до Анны Иоанновны, срисованная с гравюры А.Ф. Зубова, созданной в 1725 г. по заказу Святейшего Синода [22, стб. 217-222]. Надписи - «1758: рисовал Алексей Полозов» - под рисунками указывают на год создания и владельца рукописи - генералпоручика и камергера Алексея Семеновича Полозова (1687 - ок. 1763). На последних листах рукописи генерал зафиксировал памятные даты своей семьи: с 1755 по 1759 г. у него родились два внука и три внучки, у первых троих он стал восприемником при крещении [1, с. 36-37]. Очевидно, сборник создавался для семейной библиотеки Полозовых. Переписанные сочинения (большая часть которых это списки с изданий петровского времени) подобраны тематически и благодаря пометам на полях отражают участие члена семьи Полозовых в жизни государства.

Для памятных записей о рождении детей в семье использовался и другой сборник о Петре Великом из собрания БАН [32]. В 1771 г. по заказу отставного секунд-майора князя Михаила Афанасьевича Мышецкого отставной сержант Иван Лисятников переписывает сборник, содержащий перевод «Жития Петра Великого» Антонио Катифоро и «Историю о зачатии и рождении Петра» П.Н. Крекшина. Протографом списка послужила книга, принадлежавшая соседу Мышецких - титулярному советнику Дмитрию Васильевичу Мячкову. Судя по записям на стра- 
ницах рукописи, с 1763 по 1790 г. у М.А. Мышецкого родилось семнадцать детей, из которых в год последней записи в живых осталось пятеро. На последнем листе рукописи переписаны сведения о детях отставного секундмайора Афанасия Савича Мышецкого, отца Михаила Афанасьевича. Сведения взяты из записки его собственной руки, сделанной в «следованной псалтири».

Рукописные сборники, содержащие исторические сочинения о петровском времени, хранились в дворянских библиотеках в течение долгого времени, даже если их не использовали в качестве записных книжек. Владельческие пометы позволяют выявить типичные петровские сборники, написанные членом семьи, хранившиеся в семейной библиотеке и проданные спустя сто лет. Сборник, написанный в Москве в 1753 г. вахмистром Киевского драгунского полка Миной Тимофеевым сыном Спенковым, был приобретен капитаном Павлом Васильевичем Козакевичем в 1853 г. у «Р. Спенькова», который, судя по фамилии, был родственником создателя рукописи [35]. Сборник имеет «классический» состав: «История о зачатии и рождении Петра» П.Н. Крекшина, «Записки о Стрелецком бунте» А.А. Матвеева и «Журнал о шествии в европейские края», вставленный в записки А.А. Матвеева по хронологии. Такой же сборник был переписан сержантом Навагинского пехотного полка Петром Масаловым в 1757 г. [27].

В ряде случаев владельческие пометы отвечают на вопрос о протографах сборников. В 1765 г. капитан Егор Степанов сын Пестров переписал родословную книгу, содержащую хронологические таблицы от рождения Петpa I до коронации Елизаветы Петровны [28], и отметил, что она «списана в Санкт-Петербурге в корпусе Лейбкомпанейском с дворцовой книги». Таким образом, источником для пополнения личного книжного собрания екатерининского офицера послужила дворцовая библиотека. Пользуясь служебным положением, офицеры переписывали книги не только для себя, но для подарков: вышеупомянутый сборник позднее был подарен Андрею Сесинину.

Владельческие надписи демонстрируют популярность петровской темы и среди представителей других сословий. Так, сборник третьей четверти XVIII в., содержащий «Историю о рождении Петра Великого» П.Н. Крекшина, записки А.А. Матвеева, «Журнал о шествии», «Историческое описание о бедственном злострадании и о благополучном возшествии на престол Елисавет Петровны», а также стихотворный плач Ивана Голеневского на смерть Елизаветы Петровны, принадлежал вологодскому купцу Григорию Коробейникову [29].

На переплетном листе сборника, включавшего «Историю о рождении Петра Великого» П.Н. Крекшина, текст преамбулы Устава Морского 1720 г. и «Журнал о походе его величества Петра Перваго... при посолской свите за море в ыностранныя государства», сохранилась запись: «Сия книга московской первой гилдии купца Лаврентея Кадмина писана 1753 году, в городе Туринске с писменого журналу списана» [26].

В крестьянской среде рукописные книги с сочинениями о Петре Великом покупались, хранились и дарились также часто. Черносошный крестьянин Черевковской средней волости Даниил Табуров купил рукописный исторический сборник начала XVIII в., содержащий статейный список Е.И. Украинцева 1700 г., у «крестьянина конца Нижнаго Василия Ерасимова сына Бирачева» [30]. Иван Назарович Шестаков подписал рукописную книгу конца XVIII в. с сочинениями Антонио Катифоро и Феофана Прокоповича своему отцу, крестьянину Тотемской волости Назару Шестакову [33]. Эту книгу в 1844 г. Назар Ларионович подарил своему племяннику, волостному писарю Александру Алексеевичу Щипленцову.

Петровский сборник середины XVIII в. (с сочинениями П.Н. Крекшина, А.А. Матвеева и «Журналом о шествии») в 1823 г. принадлежал казанскому мещанину Ф.И. Рыбникову [31]. В нем также имеются владельческие записи купца первой гильдии Трофима (фамилия написана неразборчиво) и крестьянина деревни Чепчуги Степана Кириллова. Данное обстоятельство позволяет предположить, что бытование рукописных сборников о Петре Великом не ограничивали сословные барьеры.

Таким образом, последовательный кодикологический анализ дает исследователям возможность уточнить обстоятельства созда- 
ния, среду бытования и дальнейшую архивную судьбу рукописных сборников о Петре Великом. Анализ содержания сохранившихся до наших дней в архивах и библиотеках рукописных книг XVIII в. свидетельствует о том, что интерес к истории петровского времени и личности первого российского императора стимулировался не только официальной пропагандой. Изучение владельческих надписей позволяет сделать вывод о том, что сочинения о жизни и деятельности Петра Великого распространялись в списках и были популярны во всех слоях российского общества. Труды П.Н. Крекшина и А. Катифоро способствовали беллетризации истории петровского времени, превращая ее в увлекательное и поучительное семейное чтение. Использование рукописных сборников о Петре Великом в качестве записных книжек для записей семейного характера демонстрирует трансформацию исторической личности в легендарного героя общего прошлого.

\section{ПРИМЕЧАНИЯ}

${ }^{1}$ Исследование выполнено при финансовой поддержке РФФИ, проект 16-01-00192 «Петровское время в рукописной традиции XVIII-XIX вв.: исторические сочинения о Петре I и документы петровского времени в академических собраниях (БАН и Архив СПбИИ РАН)».

${ }^{2}$ Воронцов Михаил Илларионович (17141767), граф (с 1744), видный дипломат, государственный канцлер (с 1758). Воронцов Александр Романович (1741-1805), граф, президент Коммерц-коллегии и член Комиссии о коммерции (1773-1794), государственный канцлер (1802-1804).

\section{СПИСОК ЛИТЕРАТУРЫ}

1. Вознесенская, И. А. К истории создания рукописного сборника генерал-поручика Алексея Полозова (БАН, Тек. пост. 238) / И. А. Вознесенская // Петербургская библиотечная школа. - 2016. - № 2 (54). - C. 35-43.

2. [Катифоро, Антонио]. Житие Петра Великаго, императора и самодержца всероссийского, отца отечества, собранное из разных книг, во Франции и Голландии изданных, и напечатанное в Венеции, Медиолане и Неаполе на диалекте италианском, а потом и на греческом, с коего на российский язык перевел статский советник Стефан Писарев
/ [Антонио Катифоро]. - СПб. : При Императ. Акад. наук, $1772 .-511 \mathrm{c}$.

3. [Катифоро, Антонио]. Житие Петра Великого..., XVIII в. / [Антонио Катифоро] // Архив СПбИИ РАН. - Ф. 36. - Оп. 1. - № 697. - 182 л.

4. [Катифоро, Антонио]. Житие Петра Великого..., XVIII в. / [Антонио Катифоро] // Архив СПбИИ РАН. - Ф. 36. - ОП. 1. - № 700. - 121 л.

5. Копии писем и реляций Петра Великого Ф.М. Апраксину за 1700-1725 гг., XVIII в. // Архив СПбИИ РАН. - Колл. 115. - Оп. 1. - № 433. - 270 л.

6. Копии писем и реляций Петра Великого Ф.М. Апраксину за 1700-1725 гг., XVIII в. // Архив СПбИИ РАН. - Колл. 115. - Оп. 1. - № 501. - 195 л.

7. Копии писем и реляций Петра Великого Ф.М. Апраксину за 1700-1725 гг., XVIII в. // Архив СПбИИ РАН. - Колл. 115. - ОП. 1. - № 1135. - 521 с.

8. Копии писем и реляций Петра Великого Ф.М. Апраксину за 1700-1725 гг., XVIII в. // Архив СПбИИ РАН. - Колл. 238. - ОП. 1. - № 545. - 185 л.

9. Копии реляций А.Д. Меншикову за 1703 г., XVIII в. // Архив СПбИИ РАН. - Ф. 36. - Оп. 1. № $692 .-153$ л.

10. Копии реляций А.Д. Меншикову за 1704 г., XVIII в. // Архив СПбИИ РАН. - Ф. 36. - Оп. 1. № 693. -150 л.

11. Копии реляций А.Д. Меншикову за 1705 г., XVIII в. // Архив СПбИИ РАН. - Ф. 36. - Оп. 1. № 694. -148 л.

12. Копии реляций А.Д. Меншикову за 1706 г., XVIII в. // Архив СПбИИ РАН. - Ф. 36. - ОП. 1. № 695. -230 л.

13. Луппов, С. П. Печатная и рукописная книга в России в первом сорокалетии XVIII в. (проблема сосуществования) / С. П. Луппов // Рукописная и печатная книга. - М. : Наука, 1975. - С. 182-192.

14. Мезин, С. А. О первых историках Петра Великого: (заметки на полях современных изданий) / С. А. Мезин // История Петербурга. - 2009. - № 1 (47). - C. 89-94.

15. Мыльников, А. С. Вопросы изучения поздней рукописной книги (проблематика и задачи) / А. С. Мыльников // Рукописная и печатная книга. - М. : Наука, 1975. - С. 19-36.

16. Мыльников, А. С. Культурно-историческое значение рукописной книги в период становления книгопечатания / А. С. Мыльников // Книга: исследования и материалы. - М. : Изд-во Всесоюз. книж. палаты, 1964. - Сб. 9. - С. 37-53.

17. Ольшевская, Л. А. Археографический обзор списков и редакций «Путешествия по Европе боярина Б.П. Шереметева» / Л. А. Ольшевская, А. А. Решетова, С. Н. Травников // Путешествие по Европе боярина Б.П. Шереметева 1697-1699 / изд. подг. Л. А. Ольшевская, А. А. Решетова, С. Н. Травников. - М. : Наука, 2013. - С. 335-374. 
18. Описание рукописного отдела Библиотеки Академии наук СССР. 1965-1989. Т. 3. Вып. 3. Исторические сборники XVIII-XIX вв. / сост. Н. Ю. Бубнов, А. И. Копанев, М. В. Кукушкина, О. П. Лихачева. - М. ; Л. : Наука, 1971. - 420 с.

19. Петров, В. А. Обзор собрания Воронцовых, хранящегося в архиве Ленинградского отдела Института истории Академии наук СССР / В. А. Петров // Проблемы источниковедения. - М. : Изд-во AHCCCP, 1956. - T. V. - C. 102-145.

20. Подъяпольская, Е. П. Об истории и научном значении издания «Письма и бумаги императора Петра Великого» / Е. П. Подъяпольская // Археографический ежегодник за 1972 г. - М. : Наука, 1974.- C. 56-70.

21. Пыпин, А. Н. Для любителей книжной старины: библиографический список рукописных романов, повестей, сказок, поэм и пр., в особенности из первой половины XVIII в. / А. Н. Пыпин // Сборник общества любителей российской словесности на 1891 г. - М. : Типолитография т-ва И.Н. Кушнерев и К ${ }^{\circ}, 1891 .-$ С. 194-276.

22. Ровинский, Д. А. Подробный словарь русских гравированных портретов: в 2 т. / Д. А. Ровинский. - СПб. : Тип. Имп. Акад. наук, 1889. - Т. 2: П-

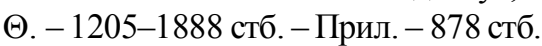

23. Розов, Н. Н. Зачем, кому и какая рукописная книга нужна была в России XVI-XIX столетий / Н. Н. Розов // Вопросы истории. - 1970. - № 6. C. 210-217.

24. Розов, Н. Н. Русская рукописная книга: этюды и характеристики / Н. Н. Розов. - Л. : Наука, 1971. $124 \mathrm{c}$.

25. Розов, Н. Н. Светская рукописная книга XVIIIXIX вв. в собрании А.А. Титова / Н. Н. Розов // Сборник ГПБ. - Л. : ГПБ, 1954. - Вып. 2. - С. 127-146.

26. Сборник, XVIII в. // Архив СПбИИ РАН. Колл. 11. - Оп. 1. - № 49. - 185 л.

27. Сборник исторический, сер. XVIII в. // БАН. - Основное собрание. - 24.5.36. - 212 л.

28. Сборник исторический, сер. XVIII в.

// БАН. - Основное собрание. - 31.3.10. - 89 л.

29. Сборник исторический, сер. XVIII в.

// БАН. - Основное собрание. - 17.8.12. 87 л.

30. Сборник исторический, нач. XVIII в.

// БАН. - Основное собрание. - 16.5.44. - 282 л.

31. Сборник исторический, сер. XVIII в.

// БАН. - Основное собрание. - 25.6.13. - 48 л.

32. Сборник исторический, сер. XVIII в. // БАН. - Собрание Археографической комиссии. № $180 .-277$ л.

33. Сборник исторический, сер. XVIII в. // БАН. - Собрание Н.Я. Колобова. - № 490. - 284 л.

34. Сборник исторический, сер. XVIII в. // БАН. - Собрание текущих поступлений. № 328. - 121 л.
35. Сборник исторический, сер. XVIII в. // БАН. - Собрание Ф.М. Плюшкина. - № 97. - 174 л.

36. Сказание о рождении, о воспитании и наречении на всероссийский царский престол его царскаго пресветлаго величества государя Петра Перваго, находящееся в библиотеке его сиятельства графа Петра Борисовича Шереметева, изданное библиотекарем Васильем Вороблевским. - М. : Тип. Пономарева, 1787. - 68 с.

37. Собрание разных записок и сочинений, служащих к доставлению полного сведения о жизни и деяниях государя императора Петра Великого / сост. Ф. О. Туманский. - СПб. : Тип. Шнора, 1787. - Ч. 1.$310 \mathrm{c}$.

38. Сперанский, М. Н. Рукописные сборники XVIII века: материалы для истории русской литературы / М. Н. Сперанский. - М. : Изд-во АН СССР, 1963. $-267 \mathrm{c}$.

39. Фокина, О. Н. Рукописные сборники XVIII века: проблемы исторической типологии / О. Н. Фокина // Книга и литература в культурном контексте : сб. науч. тр. - Новосибирск : ГПНТБ, 2003. C. $243-262$.

40. Хронологические записки достопамятных в России происшествий, XVIII в. // Архив СПбИИ РАН. - Ф. 36. - Оп. 1. - № 698. - 80 л.

\section{REFERENCES}

1. Voznesenskaya I.A. K istorii sozdaniya rukopisnogo sbornika general-poruchika Alekseya Polozova (BAN, Tek. post. 238) [On the History of Handwritten Miscellanies of Lieutenant-General Aleksey Polozov (BAN, Teck. Post. 238)]. Peterburgskaya bibliotechnaya shkola, 2016, no. 2 (54), pp. 35-43.

2. Antonio Katiforo. Zhitie Petra Velikago, imperatora $i$ samoderzhtsa vserossiyskogo, ottsa otechestva, sobrannoe iz raznykh knig, vo Frantsii $i$ Gollandii izdannykh, $i$ napechatannoe v Venetsii, Mediolane i Neapole na dialekte italianskom, a potom i na grecheskom, s koego na rossiyskiy yazyk perevel statskiy sovetnik Stefan Pisarev [The Life Chronicles of Peter the Great, Emperor and All- Russian Autocrator, Father of the Fatherland, Collected from Various Books, Published in France and Holland and Printed in Venice, Mediolane and Naples in Italian, and then in Greek, from which It was Translated into Russian by State Councilor Stephan Pisarev]. Saint Petersburg, Imp. Akad. nauk, 1772. 511 p.

3. Antonio Katiforo. Zhitie Petra Velikogo..., XVIII v. [The Life of Peter the Great..., 18th c.]. Arkhiv SPbII RAN [The Archive of Saint Petersburg Historical Institute of Russian Academy of Sciences], F. 36, Op. 1, no. 697,1821 . 
4. Antonio Katiforo. Zhitie Petra Velikogo..., XVIII v. [The Life of Peter the Great..., 18th c.]. Arkhiv SPbII RAN [The Archive of Saint Petersburg Historical Institute of Russian Academy of Sciences], F. 36, Op. 1, no. 700,1211 .

5. Kopii pisem i relyatsiy Petra Velikogo F.M. Apraksinu za 1700-1725 gg., XVIII v. [Copies of Letters and Decrees of Peter the Great to F.M. Apraksin in 1700-1725, 18th c.]. Arkhiv SPbII RAN [The Archive of Saint Petersburg Historical Institute of Russian Academy of Sciences], Col. 115, Op. 1, no. 433, 2701.

6. Kopii pisem i relyatsiy Petra Velikogo F.M. Apraksinu za 1700-1725 gg., XVIII v. [Copies of Letters and Decrees of Peter the Great to F.M. Apraksin in 1700-1725, 18th c.]. Arkhiv SPbII RAN [The Archive of Saint Petersburg Historical Institute of Russian Academy of Sciences], Col. 115, Op. 1, no. 501, 1951.

7. Kopii pisem i relyatsiy Petra Velikogo F.M. Apraksinu za 1700-1725 gg., XVIII v. [Copies of Letters and Decrees of Peter the Great to F.M. Apraksin in 1700-1725, 18th c.]. Arkhiv SPbII RAN [The Archive of Saint Petersburg Historical Institute of Russian Academy of Sciences], Col. 115, Op. 1, no. 1135, 5211.

8. Kopii pisem i relyatsiy Petra Velikogo F.M. Apraksinu za 1700-1725 gg., XVIII v. [Copies of Letters and Decrees of Peter the Great to F.M. Apraksin in 1700-1725, 18th c.]. Arkhiv SPbII RAN [The Archive of Saint Petersburg Historical Institute of Russian Academy of Sciences], Col. 238, Op. 1, no. 545, 1851.

9. Kopii relyatsiy A.D. Menshikovu za 1703 g., XVIII v. [Copies of the Reports to A.D. Menshikov for 1703, 18th c.]. Arkhiv SPbII RAN [The Archive of Saint Petersburg Historical Institute of Russian Academy of Sciences], F. 36, Op. 1, no. 692, 1531.

10. Kopii relyatsiy A.D. Menshikovu za 1704 g., XVIII v. [Copies of the Reports to A.D. Menshikov for 1704, 18th c.]. Arkhiv SPbII RAN [The Archive of Saint Petersburg Historical Institute of Russian Academy of Sciences], F. 36, Op. 1, no. 693, 1501.

11. Kopii relyatsiy A.D. Menshikovu za 1705 g., XVIII v. [Copies of the Reports to A.D. Menshikov for 1705, 18th c.]. Arkhiv SPbII RAN [The Archive of Saint Petersburg Historical Institute of Russian Academy of Sciences], F. 36, Op. 1, no. 694, 1481.

12. Kopii relyatsiy A.D. Menshikovu za 1706 g., XVIII v. [Copies of the Reports to A.D. Menshikov for 1706, 18th c.]. Arkhiv SPbII RAN[The Archive of Saint Petersburg Historical Institute of Russian Academy of Sciences], F. 36, Op. 1, no. 695, 2301.

13. Luppov S.P. Pechatnaya i rukopisnaya kniga v Rossii v pervom sorokaletii XVIII v. (problema sosushchestvovaniya) [The Printed Book and Manuscript in Russia in the First Half of the 18th Century. (The Problem of Coexistence)]. Rukopisnaya i pechatnaya kniga [Manuscript and Printed Book]. Moscow, Nauka Publ., 1975, pp. 182-192.
14. Mezin S.A. O pervykh istorikakh Petra Velikogo: (zametki na polyakh sovremennykh izdaniy) [About the First Historians of Peter the Great: (Notes on the Margins of Modern Publications)]. Istoriya Peterburga, 2009, no. 1 (47), pp. 89-94.

15. Mylnikov A.S. Voprosy izucheniya pozdney rukopisnoy knigi (problematika i zadachi) [The Issues of Studying Late Manuscript (Problems and Goals)]. Rukopisnaya i pechatnaya kniga [Manuscript and Printed Book]. Moscow, Nauka Publ., 1975, pp. 19-36.

16. Mylnikov A.S. Kulturno-istoricheskoe znachenie rukopisnoy knigi v period stanovleniya knigopechataniya [Cultural and Historical Importance of Manuscripts during the Beginning of Book Printing Period]. Kniga: issledovaniya $i$ materialy [Book: Studies and Materials]. Moscow, Izd-vo Vsesoyuz. knizh. palaty, 1964, vol. 9, pp. 37-53.

17. Olshevskaya L.A., Reshetova A.A., Travnikov S.N. Arkheograficheskiy obzor spiskov i redaktsiy «Puteshestviya po Evrope boyarina B.P. Sheremeteva» [The Archaeographic Review of Copies and Editions of "Boyar B.P. Sheremetev's Travel across Europe"]. Puteshestvie po Evrope boyarina B.P. Sheremeteva 1697-1699 [European Travel of Boyar B.P. Sheremetev 1697-1699]. Moscow, Nauka Publ., 2013, pp. 335-374.

18. Bubnov N.Yu., Kopanev A.I., Kukushkina M.V., Likhacheva O.P. Opisanie rukopisnogo otdela Biblioteki Akademii nauk SSSR. 1965-1989. T. 3. Vyp. 3. Istoricheskie sborniki XVIII-XIX vv. [Description of the Manuscript Department of the Library of USSR Academy of Sciences. 1965-1989. Vol. 3. Iss. 3. Historical Collections of the $18^{\text {th }}-19^{\text {th }} \mathrm{cc}$.]. Moscow; Leningrad, Nauka Publ., 1971. 420 p.

19. Petrov V.A. Obzor sobraniya Vorontsovykh, khranyashchegosya $\mathrm{v}$ arkhive Leningradskogo otdela Instituta istorii Akademii nauk SSSR [Review of the Vorontsovs' Collection from the Archive of the Leningrad Department of the Institute of History of the USSR Academy of Sciences]. Problemy istochnikovedeniya [Problems of Source Studies.]. Moscow, Izd-vo AN SSSR, 1956, vol. 5. pp. 102-145.

20. Podyapolskaya E.P. Ob istorii i nauchnom znachenii izdaniya «Pisma i bumagi imperatora Petra Velikogo» [On the History and Scientific Importance of the Edition "Letters and Papers of the Emperor Peter the Great"]. Arkheograficheskiy ezhegodnik za 1972 g. [Archeographic Year Book for 1972]. Moscow, Nauka Publ., 1974, pp. 56-70.

21. Pypin A.N. Dlya lyubiteley knizhnoy stariny: Bibliograficheskiy spisok rukopisnykh romanov, povestey, skazok, poem i pr., v osobennosti iz pervoy poloviny XVIII v. [For Adherents of Book Antiquity: A Bibliographic List of Handwritten Novels, Tales, Fairy Tales, Poems, etc., in Particular, from the First Half of the $18^{\text {th }}$ Century]. Sbornik obshchestva 
lyubiteley rossiyskoy slovesnosti na $1891 \mathrm{~g}$. [Proceedings of the Society of Adherents of Russian Literature in 1891]. Moscow, Tipolitografiya t-va I.N. Kushnerevi Ko, 1891, pp. 194-276.

22. Rovinskiy D.A. Podrobnyy slovar russkikh gravirovannykh portretov: $v 2 t$. [A Detailed Dictionary of Russian Engraving Portraits. In 2 vols.]. Saint Petersburg, Imp. Akad. nauk, 1889, vol. 2, pp. $1205-1888,878$.

23. Rozov N.N. Zachem, komu i kakaya rukopisnaya kniga nuzhna byla v Rossii XVIXIX stoletiy [Why, Whom and What Manuscript in Russia in the $16^{\text {th }}-19^{\text {th }}$ Centuries]. Voprosy istorii, 1970, no. 6, pp. 210-217.

24. Rozov N.N. Russkaya rukopisnaya kniga: etyudy $i$ kharakteristiki [Russian Manuscripts: Studies and Characteristics]. Leningrad, Nauka Publ., 1971. 124 p.

25. Rozov N.N. Svetskaya rukopisnaya kniga XVIII-XIX vv. v sobranii A.A. Titova [Secular Manuscripts of the $18^{\text {th }}-19^{\text {th }} \mathrm{cc}$. in the A.A. Titov's Collection]. Sbornik GPB [Collection of State Public Library]. Leningrad, GPB Publ., 1954, no. 2, pp. 127-146.

26. Sbornik, XVIII v. [Miscellany, $18^{\text {th }}$ c.]. Arkhiv SPbII RAN [The Archive of Saint Petersburg Historical Institute of Russian Academy of Sciences], Col. 11, Op. 1, no. 49, 1851.

27. Sbornik istoricheskiy, ser. XVIII v. [Historical Miscellany, mid. 18th c.]. BAN. Osnovnoe sobranie [Library of Russian Academy of Sciences. Main Collection], 24.5.36., 2121.

28. Sbornik istoricheskiy, ser. XVIII v. [Historical Miscellany, mid. 18th c.]. BAN. Osnovnoe sobranie [Library of Russian Academy of Sciences. Main Collection], 31.3.10., 891 .

29. Sbornik istoricheskiy, ser. XVIII v. [Historical Miscellany, mid. 18th c.]. BAN. Osnovnoe sobranie [Library of Russian Academy of Sciences. Main Collection], 17.8.12., 871.

30. Sbornik istoricheskiy, nach. XVIII v. [Historical Miscellany, early 18th c.]. BAN. Osnovnoe sobranie [Library of Russian Academy of Sciences. Main Collection], 16.5.44., 2821.

31. Sbornik istoricheskiy, ser. XVIII v. [Historical Miscellany, mid. 18th c.]. BAN. Osnovnoe sobranie [Library of Russian Academy of Sciences. Main Collection], 25.6.13, 481.

32. Sbornik istoricheskiy, ser. XVIII v. [Historical Miscellany, mid. 18th c.]. BAN. Sobranie Arkheograficheskoy komissii [Library of Russian
Academy of Sciences. Collection of Archaeographic Commission], no. 180, 2771.

33. Sbornik istoricheskiy, ser. XVIII v. [Historical Miscellany, mid. 18th c.]. BAN. Sobranie N.Ya. Kolobova [Library of Russian Academy of Sciences. Collection of N.Ya. Kolobov], no. 490, 2841.

34. Sbornik istoricheskiy, ser. XVIII v. [Historical Miscellany, mid. 18th c.]. BAN. Sobranie tekushchikh postupleniy [Library of Russian Academy of Sciences. Collection of Current Receipts], no. 328, 1211.

35. Sbornik istoricheskiy, ser. XVIII v. [Historical Miscellany, mid. 18th c.]. BAN. Sobranie F.M. Plyushkina [Library of Russian Academy of Sciences. Collection of F.M. Plyushkin], no. 97, 1741.

36. Skazanie o rozhdenii, o vospitanii $i$ narechenii na vserossiyskiy tsarskiy prestol ego tsarskago presvetlago velichestva gosudarya Petra Pervago, nakhodyashcheesya v biblioteke ego siyatelstva grafa Petra Borisovicha Sheremeteva, izdannoe bibliotekarem Vasilem Voroblevskim [The Story of Birth, Education and Coronation to the allRussian Tsar's Throne of His Tsar's Most High Majesty, Sovereign Peter the Great, from the Library of His Excellency Count Peter B. Sheremetev, Published by the Librarian Vasily Voroblevsky]. Moscow, Tip. Ponomareva Publ., 1787. 68 p.

37. Tumanskiy F.O., ed. Sobranie raznykh zapisok $i$ sochineniy, sluzhashchikh $k$ dostavleniyu polnogo svedeniya o zhizni i deyaniyakh gosudarya imperatora Petra Velikogo [Collection of Various Notes and Essays, Providing Complete Information about Life and Deeds of Emperor Peter the Great]. Saint Petersburg, Tip. Shnora, 1787, Part 1.310 p.

38. Speranskiy M.N. Rukopisnye sborniki XVIII veka: materialy dlya istorii russkoy literatury [Handwritten Miscellanies of the $18^{\text {th }}$ Century: Materials for the History of Russian Literature]. Moscow, Izd-vo AN SSSR, 1963. 267 p.

39. Fokina O.N. Rukopisnye sborniki XVIII veka: problemy istoricheskoy tipologii [Handwritten Miscellanies of the 18th Century: Problems of Historical Typology]. Kniga i literatura v kulturnom kontekste: sb. nauch. tr. [The Book and Literature in the Cultural Context. Collected Scientific Works]. Novosibirsk, GPNTB Publ., 2003, pp. 243-262.

40. Khronologicheskie zapiski dostopamyatnykh v Rossii proisshestviy, XVIII v. [Chronological Notes of Memorable Incidents in Russia, 18th c.]. Arkhiv SPbII RAN [The Scientific and Historical Archive of Saint Petersburg Institute of History of Russian Academy of Sciences], F. 36, Op. 1, no. 698, 801. 


\section{ИСТОРИЯ РОССИИ}

\section{Information About the Authors}

Tatyana A. Bazarova, Candidate of Sciences (History), Head of the Scientific and Historical Archive and Source Studies Group, Saint Petersburg Institute of History of RAS, Petrozavodskaya St., 7, 197110 Saint Petersburg, Russian Federation, tbazarova@yandex.ru, http://orcid.org/0000-0001-9380-5921

Irina A. Voznesenskaya, Candidate of Sciences (History), Researcher, Department of Manuscripts, Library of RAS, Birzhevaya liniya, 1, 199034 Saint Petersburg, Russian Federation, voznesen@list.ru, http://orcid.org/0000-0003-2788-9607

\section{Информация об авторах}

Татьяна Анатольевна Базарова, кандидат исторических наук, заведующая Научно-историческим архивом и группой источниковедения, Санкт-Петербургский институт истории РАН, ул. Петрозаводская, 7, 197110 г. Санкт-Петербург, Российская Федерация, tbazarova@yandex.ru, http:/ /orcid.org/0000-0001-9380-5921

Ирина Александровна Вознесенская, кандидат исторических наук, научный сотрудник, Научно-исследовательский отдел рукописей Библиотеки РАН, Биржевая линия, 1, 199034 г. СанктПетербург, Российская Федерация, voznesen@list.ru, http://orcid.org/0000-0003-2788-9607 